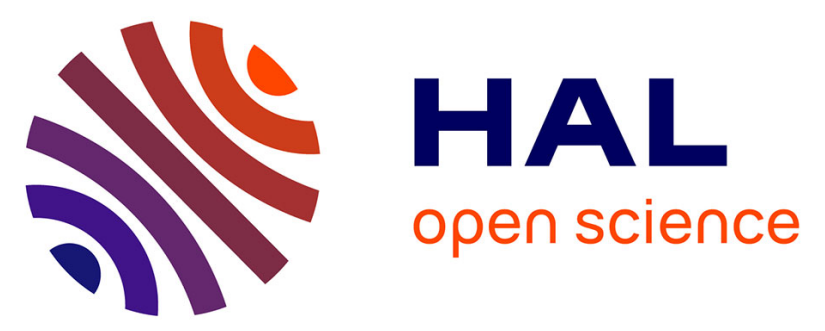

\title{
IMPAIRED MEMORY FOLLOWING PREDATORY STRESS IN MICE IS IMPROVED BY FLUOXETINE
}

\author{
Wissam El-Hage, Sylvie Peronny, Guy Griebel, Catherine Belzung
}

\section{To cite this version:}

Wissam El-Hage, Sylvie Peronny, Guy Griebel, Catherine Belzung. IMPAIRED MEMORY FOLLOWING PREDATORY STRESS IN MICE IS IMPROVED BY FLUOXETINE. Progress in Neuro-Psychopharmacology and Biological Psychiatry, 2004, 28 (1), pp.123 - 128. 10.1016/j.pnpbp.2003.09.028 . hal-02524710

\section{HAL Id: hal-02524710 \\ https://hal-univ-tours.archives-ouvertes.fr/hal-02524710}

Submitted on 30 Mar 2020

HAL is a multi-disciplinary open access archive for the deposit and dissemination of scientific research documents, whether they are published or not. The documents may come from teaching and research institutions in France or abroad, or from public or private research centers.
L'archive ouverte pluridisciplinaire HAL, est destinée au dépôt et à la diffusion de documents scientifiques de niveau recherche, publiés ou non, émanant des établissements d'enseignement et de recherche français ou étrangers, des laboratoires publics ou privés. 
El-Hage W, Peronny S, Griebel G, Belzung C. Impaired memory following predatory stress in mice is improved by fluoxetine. Progress in Neuro-Psychopharmacology \& Biological Psychiatry 2004;28(1):123-128. doi:10.1016/j.pnpbp.2003.09.028

\title{
IMPAIRED MEMORY FOLLOWING PREDATORY STRESS IN MICE IS IMPROVED BY FLUOXETINE
}

\author{
Wissam El Hage* ${ }_{\text {A }}$, Sylvie Peronny , Guy Griebel ${ }_{\text {B }}$, Catherine Belzung A
}

A EA3248 Psychobiologie des Emotions \& IFR120, Faculté Sciences \& Techniques, Parc Grandmont, 37200 Tours, France

в CNS Research Department, Sanofi-Synthelabo, 31 avenue Paul Vaillant-Couturier, 92220 Bagneux, France

*Corresponding author:

Wissam El Hage, MD, PhD

EA3248 Psychobiologie des Emotions \& IFR120, Faculté Sciences \& Techniques, Parc Grandmont, 37200 Tours - France

\begin{abstract}
.
The first purpose of the present study was to investigate possible effects of predatory stress (i.e., 5-min cat exposure) on short-term learning abilities in Swiss mice using the object recognition test (ORT). The second aim was to evaluate the effects of anxiolytics (i.e., diazepam and fluoxetine) on learning/memory abilities in the ORT following predatory stress. Results showed that predatory exposure impaired learning and produced amnesia of acquired information or impairment to retrieve learned information (48hr and $96 \mathrm{hr}$ poststressor). The learning impairment in the ORT in stressed mice was restored by acute fluoxetine treatment, but not by diazepam that instead affected learning in non-stressed animals. Taken together, these findings indicate that this animal model of exposure of mice to unavoidable predatory stimuli produces early cognitive changes analogous to those seen in patients with acute stress disorder.

Keywords.

Amnesia, fluoxetine, object recognition, predatory stress, trauma
\end{abstract}

\author{
Abbreviations. \\ ASD: Acute Stress Disorder \\ Dz: Diazepam \\ Fx: Fluoxetine \\ ns: non significative \\ ORT: Object Recognition Test \\ Phy: Physiological saline solution \\ PTSD: Post-traumatic Stress Disorder \\ PVC: Polyvinyl chloride \\ RI: Recognition Index $=100 x \operatorname{T} n /(\operatorname{Tref}+\mathrm{T} n)$ \\ SSRIs: Selective Specific Reuptake Inhibitors for serotonin \\ Tn: Time spent exploring the novel object \\ Tref: Time spent exploring the reference object
}




\section{Introduction}

In rodents and humans, stress has effects on functions of new learning and memory that are mediated by the hippocampus (Diamond et al., 1999; de Quiervain et al., 1998; Gluck et al., 1997; Lupien and Lepage, 2001), the amygdala (McGaugh, 2002) or the medial prefrontal cortex (Bremner, 2002), and on serotonergic activity (Neumaier et al., 2002). Evidence from a variety of studies (Gilbertson et al., 2001; McNally, 1998; Sutker et al., 1990; Vasterling et al., 2002) shows a relationship between exposure to a traumatic stress and deficits in memory, attention, visual spatial skills, in encoding and in retrieval on explicit memory tasks, as well as deficits in working memory (e.g., sustained attention, visuo-spatial memory, executive functions) in addition to hippocampal damage (Bremner, 1999; Diamond et al., 1996; Galletly et al., 2001). Alterations in hippocampal morphology and function are associated with numerous psychiatric disorders, e.g., one of which is posttraumatic stress disorder (PTSD). The PTSD has been linked to decreased volume of hippocampus (Bremner et al., 1995; McEven and Magarinos, 1997; Warden et al., 1996). Selective reuptake inhibitors for serotonin (SSRIs) produced an impact on this process in a beneficial way, blocking the effects of stress at the level of neurotrophic factors (Duman et al., 2001; Post et al., 1996). SSRIs have been successfully used in the clinical management of several anxiety disorders, including PTSD (Den Boer and Westenberg, 1995; Fichtner et al., 1997; Nagy et al., 1993; Van Ameringen et al., 1993). It is of particular interest that PTSD accompanied by memory impairment could be improved by treatment with SSRIs (Davis et al., 2001; Fernandez et al., 2001; Smajkic et al., 2001).

Acute Stress Disorder (ASD) (WHO, 1993; APA, 1994) is characterized by symptoms similar to those of PTSD that occur immediately in the aftermath of an extremely traumatic event (dissociative, arousal, intrusive and avoidance symptoms) (Barros et al., 2000; Bremner et al., 1998). Predatory exposure has been shown to induce anxiety-like behaviour in rodents (Adamec et al., 1999; Belzung et al., 2001; Belzung and Griebel, 2001; Blanchard et al., 1998; Blanchard et al., 1990) and can be used as a model of ASD (Adamec et al., 1997).

The present study was designed to determine whether exposure to species-relevant inescapable stress (i.e., a 5-min cat exposure) leads to acute changes in cognitive functioning using a hippocampus-related memory task, the ORT (Prickaerts et al, 2002). ORTs are widely used in rodents to test aspects of working memory and to characterize processes of amnesia (acquisition, consolidation, retrieval). In many animal models of learning and memory, the learning component consists of a stressful stimulus or food deprivation to ensure that animals are motivated to perform the task and to obtain a reward (Dodart et al., 1997). To circumvent problems with stress or food in memory tasks, the ORT was developed. It is based upon the natural tendency of mice to explore an unknown object longer than a familiar one (Poucet, 1989). An animal showing impaired memory will spend the same amount of time exploring familiar and novel objects (Messier, 1997; Dodart et al., 1997). The ORT is useful to test recognition memory in mice, allowing the assessment of acquisition, consolidation or retrieval of information. In a second phase we investigated the effects of anxiolytic drug treatments (diazepam, fluoxetine) on the impairment of learning abilities following predatory exposure.

\section{Animals, Materials and Methods}

\subsection{Ethics}

All procedures described here fully comply with French legislation on research involving animal subjects. This research protocol adhered to recommendations by the European Community Council for the Ethical Treatment of Animals (n86/609/EEC). 


\subsection{Animals}

Subjects $(\mathrm{n}=36)$ were naïve male mice Swiss aged 9 weeks at the time of testing. Animals were bred and provided by Janvier-CERJ (France). Prior to experimental testing, they were housed in groups of three in standard-sized Plexiglas cages $(30 \times 20 \times 14 \mathrm{~cm})$ permitting free access to food and water. All animals were maintained under standard laboratory conditions $\left(21-23^{\circ} \mathrm{C}\right)$ and kept on a 12-hr light/dark cycle (light onset at 7 a.m.).

\subsection{Drugs}

Diazepam $(1 \mathrm{mg} / \mathrm{kg})$ and fluoxetine hydrochloride $(10 \mathrm{mg} / \mathrm{kg})$ (synthesized by Sigma Aldrich, Saint Quentin Fallavier, France) were prepared as suspensions in physiological saline containing one drop of Tween $80(0.1 \%)$. They were injected intraperitoneally in a volume of $20 \mathrm{ml} / \mathrm{kg}, 30 \mathrm{~min}$ before test.

\subsection{Predatory exposure}

Mice were randomly assigned to the exposed or control groups. Subjects of the exposed group were confronted individually with a cat during a 5-min session. The cat (male, age 3 years; Iffa Credo, L'Arbresle, France) was placed in the exposure apparatus $(42 \times 56 \times 42 \mathrm{~cm})$ first. The mouse was placed in a Plexiglas ball (diameter $=17.5 \mathrm{~cm}$ ) containing numerous holes, and introduced into the exposure apparatus. After five minutes of exposure to the cat, the mouse was put back in its cage. Mice from the control group were handled gently and briefly in their homecage. Predatory stress or handling took place between $10 \mathrm{~h} 00$ and $15 \mathrm{~h} 00$.

\subsection{Object recognition test (ORT)}

The apparatus consisted of an illuminated (100Lux) grey PVC box $(20 \times 21 \times 32 \mathrm{~cm})$ covered with Plexiglas. The objects used were small plastic kitchen crochets from different colours and shapes, eliciting the same exploration time.

The ORT consists of three sessions, lasting 5 min each. During the first session, each subject was placed in the box empty of any object, for a 5-min habituation period. The Test 1 (second session) took place $30 \mathrm{~min}$ after the end of the habituation period. Two identical objects (reference objects) have been fixed on the wall, so that the mouse could stand up in order to explore it. The Test 2 (third session) took place one hour after the end of Test 1. One of the reference objects was replaced with a novel object. The time spent exploring the reference object (Tref) and the novel object (Tn) was recorded. A recognition index (RI) was calculated for each animal, expressed by the ratio $\mathrm{RI}=100 \mathrm{xT} n /(\mathrm{T} r e f+\mathrm{T} n)$ and compared to the value of $50 \%$ (the two objects identically explored). Between testing sessions, the box and the objects were cleaned with $10 \%$ ethanol imbibed linen. The behaviour of the mouse was observed for 5 min each session via a closed circuit TV camera by an observer located in an adjacent room, blind to the treatments of the mice. The time spent exploring each of the reference objects (snout pointing toward the object at a distance $\leq 1 \mathrm{~cm}$ ) was recorded.

\subsection{Experiment 1: Behaviour of non-exposed animals in the ORT}

A control group of 12 subjects was tested in the ORT. They were not exposed to the cat and remained untreated.

\subsection{Experiment 2: Effects of predatory exposure on memory in the ORT}

Thirty minutes after the learning session (Test 1$)$, subjects $(n=8)$ were confronted individually with a cat during a 5-min session. One hour after Test 1 the effects of cat exposure on the recent learning in the ORT (short term memory) was assessed (Test 2). 
2.8. Experiment 3: Effects of predatory exposure at different time-intervals on learning in the ORT

In order to evaluate the effects of predatory stress on learning, the predatory exposure in mice took place $48 \mathrm{hr}(\mathrm{n}=8)$ and $96 \mathrm{hr}(\mathrm{n}=8)$ before the ORT.

2.9. Experiment 4: Effects of diazepam and fluoxetine in the ORT following predatory exposure

Diazepam and fluoxetine were administered 30 min before Test 2 in the ORT (49hr after cat exposure). Forty mice were allocated to the following five groups:

(a) Naïve+saline (Phy): animals were not exposed to a cat and received physiological saline solution.

(b) Naïve+diazepam (Dz): animals were not exposed to a cat and received diazepam.

(c) Naïve+fluoxetine (Fx): animals were not exposed to a cat and received fluoxetine.

(d) Exposed+saline (E-Phy): animals were exposed to a cat $48 \mathrm{hr}$ before the ORT, and received physiological saline solution $30 \mathrm{~min}$ before Test 2 .

(e) Exposed+fluoxetine (E-Fx): animals were exposed to the cat $48 \mathrm{hr}$ before the ORT, and received fluoxetine $30 \mathrm{~min}$ before Test 2 .

Since acute administration of diazepam induced impairment of learning (Itoh et al., 1991) in the ORT in naïve Swiss mice, we did not test the effects of diazepam in exposed mice.

\subsection{Statistical analysis}

Behavioural data and comparisons between all exposure groups and controls were carried out using Student's t-tests. As some samples displayed non-normal distribution and nonhomogeneity of variances, data were analysed using non-parametric statistics (Wilcoxon test). Significance was assumed at the value $\mathrm{p}<0.05$.

\section{Results}

\subsection{Experiment 1: Behaviour of non-exposed animals in the ORT}

Results showed that there was no significant difference in the time spent exploring the two objects in any group (Test 1). This was in contrast to Test 2 where naïve animals spent more time exploring the novel object $(\mathrm{w}=23.5, \mathrm{p}=0.034)$. The $\mathrm{RI}$ was found significantly different from $50 \%(\mathrm{t}=3.003, \mathrm{p}=0.013)$.

\subsection{Experiment 2: Effects of predatory exposure on memory in the ORT}

As shown in Fig. 1, mice exposed to a cat $30 \mathrm{~min}$ after Test 1 explored similarly the two objects on the Test $2(\mathrm{t}=-1.583, \mathrm{p}=0.157)$. The RI was found not different from $50 \%(\mathrm{t}=-$ $1.011, \mathrm{p}=0.345)$.

\section{- PLEASE INSERT HERE FIGURE 1 -}

3.3. Experiment 3: Effects of predatory exposure at different time-intervals on learning in the ORT

As shown in Fig. 2, mice exposed to a cat $48 \mathrm{hr}$ before the ORT did not differentiate the novel object from the familiar one on Test $2(\mathrm{t}=0.646, \mathrm{p}=0.538)$. Mice exposed to a cat $96 \mathrm{hr}$ before the ORT explored more the novel object, but the difference was found not significative on Test $2(\mathrm{t}=1.947, \mathrm{p}=0.093)$. The RI was not significantly different from $50 \%(\mathrm{t}=2.184$, $\mathrm{p}=0.065)$. 


\subsection{Experiment 4: Effects of diazepam and fluoxetine in the ORT following predatory exposure}

As shown in Fig. 3, naïve mice that received physiological saline solution (Phy) differentiated the novel object from the reference one on Test $2(\mathrm{w}=-21.5, \mathrm{p}=0.008)$. The RI was significantly different from $50 \%(\mathrm{t}=4.267, \mathrm{p}=0.003)$. Naïve mice that received fluoxetine $(\mathrm{Fx})$ explored significantly more the novel object than the reference one on Test $2(t=2.413$, $\mathrm{p}=0.045)$. The RI was not significantly different from $50 \%(\mathrm{t}=1.02, \mathrm{p}=0.342)$. Naïve mice that received diazepam $(\mathrm{Dz})$ did not differentiate the object on Test $2(\mathrm{w}=-6.5, \mathrm{p}=0.219)$. The RI was not significantly different from $50 \%(\mathrm{t}=0.269, \mathrm{p}=0.798)$.

Exposed mice that received physiological saline solution (E-Phy) did not differentiate the object on Test 2. The RI was not significantly different from $50 \%(\mathrm{p}=\mathrm{ns})$. Exposed mice that received fluoxetine (E-Fx) explored the novel object significantly more from the reference one on Test $2(\mathrm{w}=-18, \mathrm{p}=0.008)$. The RI was significantly different from $50 \%(\mathrm{t}=9.083$, $\mathrm{p}=0.0001)$.

\section{- PLEASE INSERT HERE FIGURE 3 -}

\section{Discussion}

In the present study, exposure of mice to an unavoidable ethologically relevant predatory stress was found to be associated with impairment of learning as evidenced in the ORT. Results from pharmacological experiments showed that the administration of the 5-HT reuptake inhibitor fluoxetine improved the recognition memory in Swiss mice exposed to the predator.

The predatory exposure stress did not cause any noticeable physical harm that could explain the observed differences. One limitation of this study could be that the experiments took place under light conditions, while naturally cats predate in dark conditions. We used the Swiss strain, as it is among the most commonly line used in psychopharmacological studies, and it has been shown to be more sensitive than other strains to the administration of anxiolytics (Griebel et al., 2000).

Experiment 1 showed that naïve mice were able to discriminate between an unknown and a familiar object. In the second experiment, mice exposed to a predator after the learning session were not able to retrieve recently learned information suggesting that stress interfered with the encoding of memory. In the third experiment, $48 \mathrm{hr}$ or $96 \mathrm{hr}$ after predatory exposure, mice were not able to differentiate the two objects on the test session. Thus predatory stress in Swiss mice induced impairment in the encoding, the storage, or the retrieval of stored information.

Numerous studies showed that an acute stress has different effects on learning/memory in rodents and in humans. A bimodal response to stress was observed. A better registration of memories concerning the events occurring during the acute stress period was described by some authors (Diamond et al., 1999; Diamond and Park, 2000; Jodar et al., 1995; Jodar et al., 1996; Garcia, 2001; Vedhara et al., 2000) whereas others put in evidence of amnesic effects (Newcomer et al., 1999; Mizoguchi et al., 2000; Raghavendra et al., 1999; Holscher, 1999; Cabib and Castellano, 1997). According to the intensity of the applied stress the learning/memory abilities will be impaired (in a traumatic stress) or improved (in a nontraumatic stress). In the present study, the learning component in the ORT did not consist of any stressful stimulus, did not implicate somatomotor activity, but it measures short-term memory. Performance of the stressed group was impaired relative to that of the control group. These results are similar to those of Park et al. (2001) who found impaired habituation to a 
novel environment in the open field in rats exposed to a cat, and impaired spatial learning and memory. Stress appears to reduce the efficiency of hippocampal-related processing but does not produce the equivalent of a complete hippocampal lesion (Diamond and Park, 2000; Park et al., 2001). In the present study, ORT impairments following cat exposure may possibly reflect impairments in attentional mechanisms (novelty detection).

Traumatic stress can cause a range of functional deficits. Our findings of impaired memory in mice following predatory stress may parallel human work in that people with PTSD exhibit impaired cognitive functioning (Bremner, 1999; Bremner et al., 1993, 1995; Yehuda et al., 1995). SSRIs, including fluoxetine, are effective in the treatment of the entire spectrum of posttraumatic symptoms (Fernandez et al., 2001; Hidalgo and Davidson, 2000; Van der Kolk, 1994), and may affect the serotoninergic activity particularly in the hippocampus (Belzung et al., 2001). As such, the present results with fluoxetine indicate an effect on stress, rather than learning (no positive effect in naïve mice). It can reasonably be suggested that fluoxetine opposes the negative impact of traumatic stress on memory. However our findings do not parallel human work as such effects are usually described as long-term posttraumatic effects (PTSD-like), whereas here we deal with short-term effects (ASD-like).

\section{Conclusion}

Previous studies showed that the acute unpredictable predatory stress produce in mice behavioural and neurochemical changes consistent with increased anxiety. The present findings, taken together, indicate that acute unpredictable predatory stress induces short-term memory changes ameliorated by fluoxetine treatment.

\section{References}

American Psychiatric Association, 1994. Diagnostic and Statistical Manual of Mental Disorders, fourth ed. American Psychiatric Press, Washington, DC.

Adamec, R.E., Burton, P., Shallow, T., Budgell, J., 1999. NMDA receptors mediate lasting increases in anxiety-like behavior produced by the stress of predator exposure implications for anxiety associated with posttraumatic stress disorder, Physiol. Behav. 65 (4-5), 723-737.

Adamec, R.E., Shallow, T., Budgell, J., 1997. Blockade of CCKB but not CCKA receptors before and after the stress of predator exposure prevent lasting increases in anxiety-like behavior: implications for anxiety associated with posttraumatic stress disorder, Behav. Neurosci. 111 (2), 435-449.

Barros, M., Boere, V., Huston, J.M., Tomaz, C., 2000. Measuring fear and anxiety in the marmoset (Callithrix penicillia) with a novel predator confrontation model: effects of diazepam, Behav. Brain Res. 108, 205-211.

Belzung, C., El Hage, W., Moindrot, N., Griebel, G., 2001. Behavioral and neurochemical changes following predatory stress in mice, Neuropharmacology 41, 400-408.

Belzung, C., Griebel, G., 2001. Measuring normal and pathological anxiety-like behaviour in mice: a review, Behav. Brain Res. 125, 141-149.

Blanchard, R.J., Blanchard, D.C., Rodgers, J., Weiss, S.M., 1990. The characterization and modeling of Antipredator defensive behavior, Neurosci. Biobehav. Rev. 14, 463-472.

Blanchard, R.J., Nikulina, J.N., Sakai, R.R., McKittrick, C., McEwen, B., Blanchard, D.C., 1998. Behavioral and endocrine change following chronic predatory stress, Physiol. Behav. 63 (4), 561-569.

Bremner, J.D., 1999. Does stress damage the brain? Biol. Psychiatry 45, 797-805.

Bremner, J.D., 2002. Neuroimaging studies in post traumatic stress disorder, Curr. Psychiatry Rep. 4, 254-263. 
Bremner, J.D., Randall, P., Scott, T.M., Bronen, R.A., Seibyl, J.P., Southwick, S.M., Delaney, R.C., McCarty, G., Charney, D.S., 1995. Magnetic resonance imaging-based measurement of hippocampal volume in patients with combat-related posttraumatic stress disorder, Am. J. Psychiatry 152, 973-981.

Bremner, J.D., Scott, T.M., Delaney, R.C., Southwick, S.M., Mason, J.W., Johnson, D.R., Innis, R.B., McCarty, G., Charney, D.S., 1993. Deficits in short-term memory in posttraumatic stress disorder, Am. J. Psychiatry 150, 1015-1019.

Bremner, J.D., Vermetten, E., Southwick, S.M., Krystal, J.H., Charney, D.S., 1998. Trauma, memory, and dissociation: an integrative formulation. In: Bremner, J.D., Marmar, C.A. (Eds.), Trauma, memory, and dissociation, American Psychiatric Press, Washington, DC, pp. 365-402.

Cabib, S., Castellano, C., 1997. Impairments produced by amphetamine and stress on memory storage are reduced following a chronic stressful experience, Psychopharmacology (Berl) 129 (2), 161-167.

Davis, L.L., English, B.A., Ambrose, S.M., Petty, F., 2001. Pharmacotherapy for posttraumatic stress disorder: a comprehensive review, Expert Opin. Pharmacother. 2 (10), 1583-1595.

Den Boer, J.A., Westenberg, H.G.M., 1995. Serotonergic compounds in panic disorder, obsessive-compulsive disorder and anxious depression: A concise review, Hum. Psychopharmacol. Clin. Exp. 10, S173-S183.

Diamond, D.M., Fleshner, M., Ingersoll, N., Rose, G.M., 1996. Psychological stress impairs spatial working memory: relevance to electrophysiological studies of hippocampal function, Behav. Neurosci. 110 (4), 661-672.

Diamond, D.M., Park, C.R., 2000. Predator exposure produces retrograde amnesia and blocks synaptic plasticity. Progress toward understanding how the hippocampus is affected by stress, Ann. N. Y. Acad. Sci. 911, 453-455.

Diamond, D.M., Park, C.R., Heman, K.L., Rose, G.M., 1999. Exposing rats to a predator impairs spatial working memory in the radial arm water maze. Hippocampus 9, 542-552.

Dodart, J.C., Mathis, C., Ungerer, A., 1997. Scopolamine-induced deficits in a two-trial object recognition task in mice, Neuroreport 8 (5), 1173-1178.

Duman, R.S., Nakagawa, S., Malberg, J., 2001. Regulation of adult neurogenesis by antidepressant treatment, Neuropsychopharmacology 25, 836-844.

Fernandez, M., Pissiota, A., Frans, O., von Knorring, L., Fischer, H., Fredrikson, M., 2001. Brain function in a patient with torture related post-traumatic stress disorder before and after fluoxetine treatment: a positron emission tomography provocation study, Neurosci. Lett. 297 (2), 101-104.

Fichtner, C.G., Poddig, B.E., deVito, R.A., 1997. Post-traumatic stress disorder: Pathophysiological aspects and pharmacological approaches to treatment, Drugs 8, 293322.

Galletly, C., Clark, C.R., McFarlane, A.C., Weber, D.L., 2001. Working memory in posttraumatic stress disorder - An event-related potential study, J. Trauma. Stress 14 (2), 295-309.

Garcia, R., 2001. Stress, hippocampal plasticity, and spatial learning, Synapse 40, 180-183.

Gilbertson, M.W., Gurvits, T.V., Lasko, N.B., Orr, S.P., Pitman, R.K., 2001. Multivariate assessment of explicit memory function in combat veterans with posttraumatic stress disorder, J. Trauma. Stress 14 (2), 413-432.

Gluck, M.A., Ermita, B.R., Oliver, L.M., Myers, C.E., 1997. Extending models of hippocampal function in animal conditioning to human amnesia, Memory 5 (1-2), 179212. 
Griebel, G., Belzung, C., Perrault, G., Sanger, D.J., 2000. Differences in anxiety-related behaviours and in sensitivity to diazepam in inbred and outbred strains of mice, Psychopharmacology (Berl) 148, 164-170.

Hidalgo, R.B., Davidson, J.R., 2000. Selective serotonin reuptake inhibitors in post-traumatic stress disorder, J. Psychopharmacol. 14 (1), 70-76.

Holscher, C., 1999. Stress impairs performance in spatial water maze learning tasks, Behav. Brain Res. 100 (1-2), 225-235.

Itoh, J., Nabeshima, T., Kameyama, T., 1991. Utility of an elevated plus-maze for dissociation of amnesic and behavioral effects of drugs in mice, Eur. J. Pharmacol. 194 (1), 71-76.

Jodar, L., Takahashi, M., Kaneto, H., 1995. Effects of footshock-, psychological- and forced swimming-stress on the learning and memory processes: involvement of opioidergic pathways, Jpn. J. Pharmacol. 67 (2), 143-147.

Jodar, L., Takahashi, M., Kaneto, H., 1996. FS stress induces long-lasting memory facilitation: involvement of cholinergic pathways, Pharmacol. Biochem. Behav. 53 (3), 735-740.

Lupien, S.J., Lepage, M., 2001. Stress, memory, and the hippocampus: can't live with it, can't live without it, Behav. Brain Res. 127 (1-2), 137-158.

McEven, B.S., Magarinos, A.M., 1997. Stress effects on morphology and function of the hippocampus, Ann. N. Y. Acad. Sci. 821, 271-284.

McGaugh, J.L., 2002. Memory consolidation and the amygdala: a systems perspective, Trends Neurosci. 25 (9), 456-461.

McNally, R.J., 1998. Experimental approaches to cognitive abnormality in posttraumatic stress disorder, Clin. Psychol. Rev. 18 (8), 971-982.

Messier, C., 1997. Object recognition in mice: improvement of memory by glucose, Neurobiol. Learn. Mem. 67 (2), 172-175.

Mizoguchi, K., Yuzurihara, M., Ishige, A., Sasaki, H., Chui, D.H., Tabira, T., 2000. Chronic stress induces impairment of spatial working memory because of prefrontal dopaminergic dysfunction, J. Neurosci. 20 (4), 1568-1574.

Nagy, L.M., Morgan, C.A.3, Southwick, S.M., Charney, D.S., 1993. Open prospective trial of fluoxetine for posttraumatic stress disorder, J. Clin. Psychopharmacol. 13, 107-113.

Neumaier, J.F., Edwards, E., Plotsky, P.M., 2002. 5-HT1B mRNA regulation in two animal models of altered stress reactivity, Biol. Psychiatry 51, 902-908.

Newcomer, J.W., Selke, G., Melson, A.K., Hershey, T., Craft, S., Richards, K., Alderson, A.L., 1999. Decreased memory performance in healthy humans induced by stress-level cortisol treatment, Arch. Gen. Psychiatry 56 (6), 527-533.

Park, C.R., Campbell, A.M., Diamond, D.M., 2001. Chronic psychosocial stress impairs learning and memory and increases sensitivity to yohimbine in adult rats, Biol. Psychiatry 50 (12), 994-1004.

Post, R.M., Smith, M., Weiss, S.R.B., Beaulieu, S., Chuang, D.M., 1996. Opposing effects of stress and antidepressants of neurotrophic factors, Eur. Neuropsychopharmacol. 6 (3), 9697.

Poucet, B., 1989. Object exploration, habituation, and response to a spatial change in rats following septal or medial frontal cortical damage, Behav. Neurosci. 103 (5), 1009-1016.

Prickaerts, J., de Vente, J., Honig, W., Steinbusch, H.W.M., Blokland, A., 2002. cGMP, but not camp, in rat hippocampus is involved in early stages of object memory consolidation, Eur. J. Pharmacol. 436, 83-87.

de Quervain, D.J., Roozendaal, B., McGaugh, J.L., 1998. Stress and glucocorticoids impair retrieval of long-term spatial memory, Nature 394 (6695), 787-790. 
Raghavendra, V., Chopra, K., Kulkarni, S.K., 1999. Brain renin angiotensin system (RAS) in stress-induced analgesia and impaired retention, Peptides 20 (3), 335-342.

Smajkic, A., Weine, S., Duric-Bijedic, Z., Boskailo, E., Lewis, J., Pavkovic, I., 2001. Sertraline, paroxetine and venlafaxine in refugee post traumatic stress disorder with depression symptoms, Med. Arh. 55 (1 Suppl. 1), 35-38.

Sutker, P.B., Galina, Z.H., West, J.A., Allain, A.N., 1990. Trauma-induced weight loss and cognitive deficits among former prisoners of war, J. Consult. Clin. Psychol. 58 (3), 323328.

Van Ameringen, M., Mancini, C., Streiner, D.L., 1993. Fluoxetine efficacy in social phobia, J. Clin. Psychiatry 54, 27-32.

Van der Kolk, B.A., 1994. The body keeps the score: memory and the evolving psychobiology of posttraumatic stress, Harvard Rev. Psychiatry 1, 253-265.

Vasterling, J.J., Duke, L.M., Brailey, K., Constans, J.I., Allain, A.N. Jr., Sutker, P.B., 2002. Attention, learning, and memory performances and intellectual resources in Vietnam veterans: PTSD and no disorder comparisons, Neuropsychology 16 (1), 5-14.

Vedhara, K., Hyde, J., Gilchrist, I.D., Tytherleigh, M., Plummer, S., 2000. Acute stress, memory, attention and cortisol, Psychoneuroendocrinology 25 (6), 535-549.

Warden, D., Reider-Groswasser, I., Grafman, J., Salazar, A., 1996. PTSD and hippocampal volume, Am. J. Psychiatry 153 (12), 1657.

World Health Organization, 1993. The ICD-10 Classification of Mental and Behavioural disorders: Diagnostic criteria for research, WHO, Geneva.

Yehuda, R., Keefe, R.S., Harvey, P.D., Levengood, R.A., Gerber, D.K., Geni, J., Siever, L.J., 1995. Learning and memory in combat veterans with posttraumatic stress disorder, Am. J. Psychiatry 152, 137-139.

Figure 1. Effects of unavoidable cat exposure on the time spent by Swiss mice exploring familiar object and novel object on Test 2 of the ORT (experiment 2: effects on memory). The mice were exposed to a cat between Test 1 and 2 of the ORT. Data represent mean \pm S.E. $*<0.05$ (vs. control group).

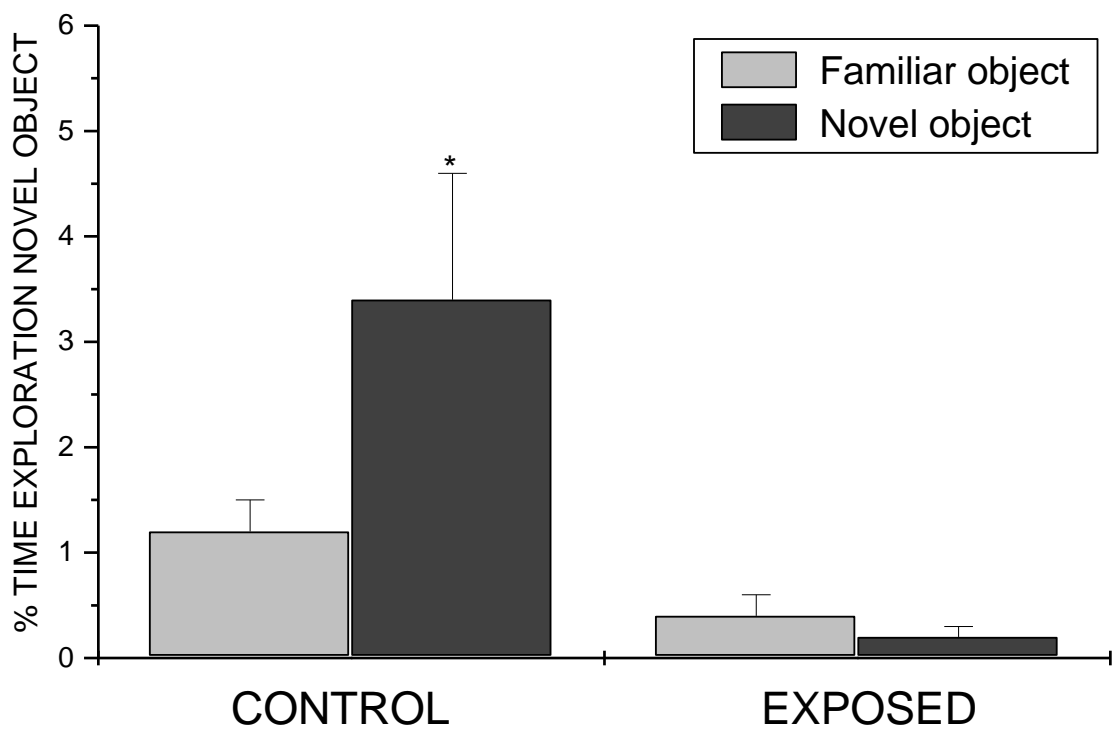


Figure 2. Effects of unavoidable cat exposure on the time spent by Swiss mice exploring familiar object and novel object on Test 2 of the ORT (experiment 3: effects on learning). The mice were exposed to a cat $48 \mathrm{hr}$ or $96 \mathrm{hr}$ before the ORT. Data represent mean \pm S.E. $*<0.05$ (novel vs. familiar).

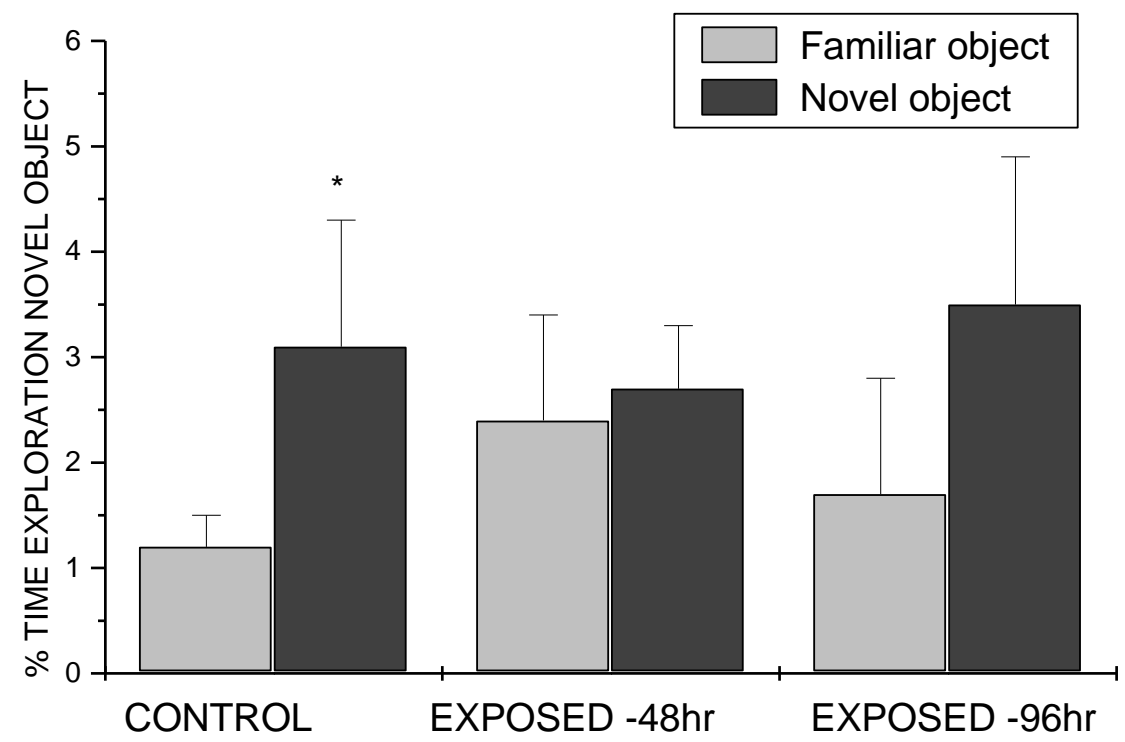

Figure 3. Effects of diazepam $(1 \mathrm{mg} / \mathrm{kg})$ and fluoxetine $(10 \mathrm{mg} / \mathrm{kg})$ on exploration of novel object in Swiss mice confronted to unavoidable predatory stress $49 \mathrm{hr}$ before the ORT. We distinguish five groups: Naïve+saline (Phy), Naïve+fluoxetine (Fx), Exposed+saline (E-Phy), Exposed+fluoxetine (E-Fx). Data represent mean \pm S.E. $*<0.05$ (novel vs. familiar).

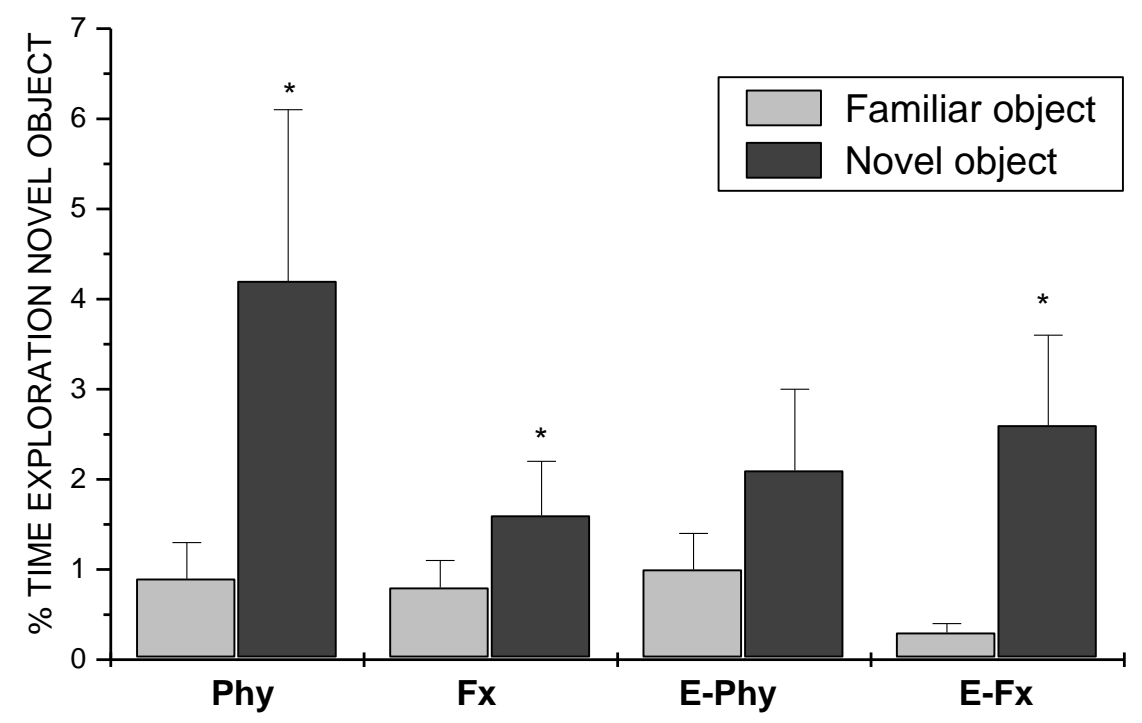

